\title{
Performances no mundo do livro: entre a história, a memória e a ficção
}

Eliana de Freitas Dutra ${ }^{*}$

${ }^{1}$ Universidade Federal de Minas Gerais, Belo Horizonte/ MG - Brasil

\section{RESUMO}

Neste artigo, objetivamos analisar como ficcionistas, ensaístas e memorialistas elaboram histórias de experiências com a leitura e as bibliotecas no interior de uma cultura do livro no Ocidente e com pontos de contato com a história dos livros, da ediçấo e da leitura, a partir do pressuposto da plasticidade existente entre esses gêneros de escrita. $O$ texto explora, por meio de certas tópicas, representaçóes, metáforas e alegorias recorrentes em escritos centrados na temática de livros, bibliotecas e leitores. A intenção é mostrar o livro como matéria de ficção, exercício de memória e objeto de análise; como a ficção e o ensaísmo podem ser um modo de interrogação da história e de dar forma à memória; e como a memória e a percepção do tempo podem ser mediados pelos livros e pelos atos de leitura.

Palavras-chave: livros; ficção; ensaios; memória; tempo.

\section{Performances in the world of books: between history, memory and fiction}

\begin{abstract}
In this article, we analyze how writers of fiction, essays, and memoirs create stories of experiences with reading and libraries within Western book culture and with influences from different genres, such as the histories of books, editing, and reading. This text uses certain topics to explore recurrent representations, metaphors, and allegories present in writings about books, libraries, and readers. The intention is to depict the book as a fictional subject,
\end{abstract}

DOI: http://dx.doi.org/10.1590/2237-101X02104508.

Artigo recebido em 2 de agosto de 2019 e aceito para publicação em 12 de fevereiro de 2020.

*Professora da Universidade Federal de Minas Gerais / Faculdade de Filosofia e Ciências Sociais / Departamento de História, Belo Horizonte/ MG - Brasil. Bolsista CNPq PQ-1A. E-mail: erdutra@terra.com.br. ORCID: https://orcid.org/0000-0002-4688-4169.

Uma versão preliminar deste texto foi apresentada na $24^{\text {th }}$ Annual Conference of the Society for the History of Authorship, Reading \& Publishing (SHARP), realizada na Biblioteca Nacional da França, em 2016. Agradeço ao CNPq, pelo apoio às minhas pesquisas, e aos amigos Cacá Leite Brandão, Giselle Venancio e Regina Horta Duarte pela leitura generosa dos originais. Dedico este artigo a Alencar e demais amigos da Livraria Quixote. 
an exercise in memory, and an object of analysis; to show how fiction and essay writing can be both a way of questioning history and of giving shape to memory; and to show how memory and perception of time can be mediated by books and by the act of reading.

Keywords: books; fiction; essays, memory, time.

\section{Interpretación en el mundo del libro: entre la historia, la memoria y la ficción}

\section{RESUMEN}

En este artículo pretendemos analizar cómo los partidarios de la ficción, ensayistas y moralistas elaboran historias de experiencias con la lectura y las bibliotecas en el interior de una cultura del libro en Occidente y con los puntos de contacto con la historia de los libros, de la edición y de la lectura, a partir del presupuesto de la plasticidad existente entre esos géneros de la escritura. El texto explora, por medio de ciertos tópicos, representaciones, metáforas y alegorías recurrentes en escritos centrados en la temática de libros, bibliotecas y lectores. La intención es mostrar el libro como materia de ficción y de análisis; cómo la ficción y el ensayismo pueden ser un modo de interrogación de la historia y de dar forma a la memoria; y cómo la memoria y la percepción del tiempo pueden ser medidos por los libros y por los actos de lectura.

Palabras clave: libros; ficción; ensayos; memoria; tiempo.

\section{Fontes de inspiração}

A ideia deste texto surgiu de duas fontes inspiradoras. A primeira, devemos confessá-lo, está associada à atração colecionista desta autora em acumular livros cujo tema esteja relacionado a livros, leitores, bibliófilos e bibliotecas. A outra fonte, por sua vez, tem a ver com a leitura de um pequenino livro dessa coleção. Trata-se de O fim dos livros (UZANNE, 2010), uma ficção publicada em 1874, na França, escrita pelo bibliófilo, jornalista, editor e literato francês Octave Uzanne, e ilustrada pelo artista Albert Robida, francês, caricaturista, litógrafo, novelista e visionário que antecipou certo número de invençóes científicas. Nesse romance, cuja história se passa em Londres, um grupo de cientistas e artistas (naturalistas, químicos, bibliófilos, pintores, críticos de arte), após uma conferência na Academia Real de Ciências, vai jantar em um clube masculino e o assunto da conversação incide sobre o destino da humanidade em face do progresso e das novas tecnologias. Cada um é convidado a apresentar o seu ponto de vista em relação ao futuro em seu respectivo domínio. E o bibliófilo, questionado a respeito 
do destino reservado às letras, aos livros e à literatura dali a cem anos, não hesita em prever o desaparecimento do livro. Em substituiçáo aos cadernos em papel dobrados, brochuras sob uma capa com o título da obra, ele antecipa a chegada de um fonógrafo de celuloide, leve como uma pluma, portanto, pronto para ser transportado no bolso, com a gravação de sua própria voz. Em vez dos autores, nomeados como escritores e homens de letras, os narradores; no lugar da escrita, a voz; o autor seria seu próprio editor nos livros, sobreviventes, de novela ou de historiografia, e teria a possibilidade de registrar e patentear a sua voz para se precaver contra a falsificaçáo. Interrogado sobre o destino das bibliotecas, nosso personagem vislumbra sua nomeação como fonografotecas ou registrotecas. E ediçôes de autores famosos seriam autofonografadas por artistas consagrados do teatro, da poesia e da música que emprestariam sua voz às desses autores. Fonistas e clamistas ocupariam assim o lugar até entâo reservado aos secretários e copistas. A voz é que daria "variantes imprevistas e inéditas de uma obra célebre" (UZANNE, 2010, p. 58), atuando sobre a produção do sentido. No interior dessa revolução do livro - que poria fim, segundo nosso personagem, à tirania da gráfica, em ação desde o século XV - o bibliófilo se transmutaria em fono-grafiológico. O desaparecimento do livro, no seu tradicional suporte, pelo fonografismo, em sua opinião, facilitaria a vida dos leitores em deslocamento, a passeio ou mesmo em casa, com a fabricaçáo de fono-operadores de bolso e prometia um futuro mais democrático, com distribuidores literários espalhados pela rua disponibilizando audiçóes a baixo custo. $\mathrm{O}$ fim dos livros impressos, assim, corresponderia a uma medida necessária para impedir a multiplicação, em cada ano, de milhôes de exemplares "repletos de extravagância e de quimeras malucas, limitando-se a difundir preconceitos e erros" (p. 80) e, nessa condição, ele denuncia, os livros seriam capazes, portanto, de devorar os homens.

Além dos detalhes relacionados com a nova invenção - aliás, designada pelo autor como brincadeira, - ele não se esquece de observar, em compensação, que a sua predição continha alguns elementos verídicos. E conta que, no desfecho desse jantar, no momento da separação do grupo, um dos participantes teria afirmado com voz forte: "Mas que felicidade não ter mais que ler, e de poder, enfim, fechar os olhos para o vazio dos impressos! Jamais o Hamlet de nosso grande Will não teria dito melhor: 'Words, words, words. Palavras! Palavras que passam e não as leremos mais" (UZANNE, 2010, p. 80). No ato de conclusão dessa sua frase, segundo o autor, o personagem teria sido aplaudido com muito entusiasmo por todos.

Aqui, gostaríamos de sublinhar como esse pequeno romance, à sua maneira ${ }^{2}$, nos instiga a pensar em temas bastante atuais. A saber: a crise da leitura, a revolução ou o fim do livro, o

\footnotetext{
${ }^{2}$ Referimo-nos ao fato de que a perspectiva visionária de Octave Uzanne, afinada com a celebraçáo das inovaçóes da modernidade, guarda pontos de contato com o utopismo francês do século XIX, ao qual não faltou o ímpeto de tentar romper com as antigas tradiçóes através do instrumento da ciência, da técnica ou da política. Na obra de Uzanne, no entanto, sua manifestação se deu pela valorização conjunta da arte e da técnica, tendo como objeto privilegiado os livros, e do seu interesse bibliófilo pelos aspectos técnicos da edição, da impressão, da reimpressão das imagens, da arte da encadernação, apurados no seu diálogo com ilustradores, artistas, tipógrafos e outros bibliófilos com os quais esteve engajado em sociedades de amigos dos livros.
} 
tempo do texto eletrônico, a morte ou a transfiguração do leitor, um mundo sem autor, enfim, a presença insidiosa da internet, questóes novas referentes aos direitos autorais e à inteligência coletiva, os quais em anos recentes têm presença assegurada nos domínios da historiografia do livro, da edição e da leitura. Não por acaso, esses temas têm atraído a atenção de historiadores que se tornaram referências nesse campo, tais como Jean-Yves Mollier (2002), Roger Chartier (2002), Alberto Manguel (2006), Antoine Compagnon (2002) e muitos outros, bem como de semiólogos, caso de Umberto Eco (2010), e do escritor e dramaturgo Jean-Claude Carrière (2010). Afinal, o mundo do livro, seja no seu sentido amplo, seja frente à diversificação dos atores do livro, de suas práticas, e da multiplicidade das suas formas de comunicação e linguagem, sempre despertou enorme interesse de especialistas e não especialistas. E não deixa de ser no mínimo curioso que, tal como no livro de Octave Uzanne, O fim dos livros, nos defrontemo-nos hoje com vários títulos de livros que à sua maneira nos falam de autores que ou tematizam uma certa obsessão pelo tema do desaparecimento dos livros, dos leitores e/ou dos últimos livros, ou que realizam, na chave da crítica literária e histórica, reflexóes sobre o significado da leitura, o ato de ler e colecionar, as relaçóes de autores e leitores com o livro como objeto material, suporte impresso, e a condição de "ser" dos homens.

Dito isso, para o que nos interessa aqui, podemos mencionar a existência de uma vertente acadêmica, seja no interior do ensaísmo e de uma história do livro, da leitura e da ediçáo com todas as suas variantes; de uma vertente ficcional, nos romances e contos; e de uma vertente memorial baseada nas relaçóes pessoais e familiares com os livros e a leitura. Nessa trilha nos defrontamos com percepçóes acerca de leitores reais e imaginários, leitores presumidos, leitores ficcionais, os quais deslocam-se todos, afinal de contas, entre a realidade, o desejo e a imaginação.

Nosso texto tentará estabelecer uma articulação entre esses campos por intermédio das construçôes discursivas e suas figuraçóes sobre os livros, leitores, bibliotecas e atores do livro, analisando especialmente os cruzamentos entre determinados autores da história do livro, da edição e da leitura, por um lado; e, por outro, alguns ensaístas e literatos, os quais tomaram os livros como objeto de ficção ou de memória, ou construíram uma história imaginária da leitura com possíveis repercussóes hermenêuticas sobre a escrita dos historiadores, levando-se em conta as suas afinidades, os seus encontros, as suas tensóes e os seus contrastes. Por meio dessas aproximaçôes, nosso objetivo, portanto, consiste em demonstrar sejam as diferentes - mas não forçosamente antagônicas - maneiras de falar dos livros, das bibliotecas, dos leitores, e de escrever a história deles, sejam as dimensóes performativas implicadas nesses atos e nos seus atores. Estas estarão no horizonte analítico dos textos aqui analisados, em que a encenação do espetáculo da escrita "designa o lado de visibilidade que se acrescenta ao lado de lisibilidade da intriga”, tal como nos lembra Paul Ricoeur ${ }^{3}$. É a performance ${ }^{4}$ que nas

\footnotetext{
${ }^{3}$ No seu comentário dos componentes da intriga na Poética de Aristóteles e das implicaçóes da encenação na forma produzida pelo escrito: "Il désigne le côté de visibilité qui s'ajoute au côté de lisibilité" (RICOEUR, 2000, p. 314).

${ }^{4}$ Cabe assinalar que a noção de performance tem sido trabalhada como opção teórico-metodológica para a
} 
diferentes escritas sobre os livros, as bibliotecas e os leitores, incluída aí a história, responde pela encenação da intriga.

Para isso, em um grupo vasto, mas não exaustivo, de obras disponíveis, partimos de dois critérios de leitura para circunscrever em melhores condiçóes tais contrastes e aproximaçóes. Um deles diz respeito à escolha de algumas, dentre inúmeras obras de ficção, ensaios e memórias, cujas leituras nos sugeriam elementos significativos em relação a nosso intuito. Limitamos nossa escolha a alguns títulos pelas possibilidades de diálogo que vimos se descortinarem entre elas e, posteriormente, pela fecundidade vislumbrada no cotejo delas com

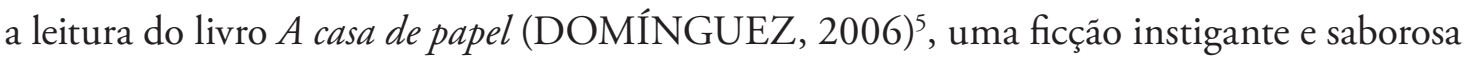
do escritor argentino Carlos Maria Domínguez. Escolhemos esse livro como âncora deste artigo enquanto uma linha sugestiva de um percurso capaz de permitir um arranjo, que eu diria mesmo poético, da arquitetura de um texto que escolheu lidar com representaçóes, metáforas e alegorias escolhidas - pela sua recorrência - em produçóes textuais acadêmicas, ficcionais e memoriais que tomaram os livros, leitores e assemelhados como objeto. Ao longo do texto as demais obras escolhidas entraráo em cena. Alguns dos autores aqui escolhidos são, ou foram também, verdadeiros bibliófilos.

O segundo critério consistiu no mapeamento - no interior do conjunto de títulos escolhidos - de algumas tópicas comuns enquanto ferramenta da arquitetura dos textos, da produção de sentidos para a leitura e da expressão do atrativo e do valor dos livros e da leitura. Ou seja, a tópica entendida como organizadora dos procedimentos inventivos, criativos, dos textos. A ideia de um percurso no tema deste texto por meio das tópicas vem igualmente do pressuposto segundo o qual a literatura, a história e o ensaísmo, no seu esforço narrativo e produção de significados, se movem em espaços e constroem lugares textuais. Assim, vamos proceder à análise de algumas tópicas, tais como a viagem, o poder, o perigo, a paixão e o desejo, a loucura, o corpo, a ordem e o duplo. Estas são bastante frequentes quando o objeto da escrita são os livros, os leitores, as bibliotecas, os bibliófilos, as livrarias e os tipógrafos.

Essas tópicas não são exclusivas de um só universo textual, seja o ficcional, o ensaístico, o memorial ou o acadêmico: pelo contrário, verifica-se que elas se cruzam nesses diferentes campos, nos quais dáo corpo às intrigas encenadas e plasmam a experiência da leitura e da biblioteca no imaginário ocidental moderno.

A forma mais ensaística deste texto pareceu-nos ser a mais coerente de maneira a produzir uma interpretação persuasiva e empática do corpus, a partir não de relaçôes causais

saída da cultura escrita e do plano discursivo. Este é o caso de $O$ arquivo e o repertório. Performance e memória cultural nas Américas (2013), de Diana Taylor. Neste livro a autora faz uma valiosa reflexão com ênfase na dimensão do performático, no campo do que qualifica como cultura incorporada. Como aqui estamos privilegiando o domínio do texto, da literatura, e não do gesto, do movimento e da oralidade, optamos, pois, em alinhamento com Ricoeur, por ater-nos às coreografias de sentido dos textos.

${ }^{5}$ Agradecemos ao amigo Nélson Schapochnik pela indicação deste livro, cuja leitura foi mais útil do que poderíamos supor. 
entre os textos e autores, mas do pressuposto reflexivo da plasticidade dos gêneros textuais, do potencial dialógico que eles propiciam e das ferramentas de inteligibilidade que, de seus respectivos lugares de agenciamento, os textos disponibilizam para o manuseio das tópicas selecionadas. Estas também se compóem entre si, alimentando várias representações, metáforas e alegorias no interior de cada um desses universos: é o caso do romance intitulado $A$ casa de papel. Vamos nos deter um pouco mais sobre esse livro, uma vez que, como já assinalado, foi ele o guia para nossa abordagem neste texto.

\section{A viagem e o tempo: o começo de um percurso}

A trama desse livro sobre a paixão pelos livros, pelas bibliotecas e pela literatura organiza-se em torno de dois acontecimentos principais: a morte por atropelamento de Bluma - uma professora da Universidade de Cambridge -, no momento em que ela atravessava uma rua enquanto lia um exemplar do Poema de Emily Dickinson. O outro acontecimento refere-se a um livro, $A$ linha de sombra, de Joseph Conrad, enviado do Uruguai - endereçado a essa professora e entregue após a sua morte - por um colega professor de literatura hispânica, que vem a ser o próprio narrador dessa história. O livro em pauta estava sujo, tendo sobre a capa uma crosta de concreto, de cimento, e, no interior, uma dedicatória da mulher falecida a um "nome", desconhecido, Carlos. Intrigado com esse livro sujo reencaminhado a Bluma, o professor/narrador descobre que a sua colega tivera, por ocasião de um congresso de literatos em Monterrey, no México, um caso amoroso com um bibliófilo uruguaio chamado Carlos Bauer. Daí ele decide, então, fazer uma viagem (a primeira das tópicas) a Montevidéu para desvendar o mistério. Sua busca de pistas vai introduzi-lo em um mundo de bibliófilos ao qual pertencia a pessoa, o Carlos, que ele procurava: Carlos Bauer. Em Montevidéu, ele encontra um homem das relaçóes de Carlos Bauer, chamado Delgado, que lhe fornece as informaçôes para resolver o enigma. Esse homem era também um bibliófilo apaixonado, um colecionador culto que vivia no meio de livros; além disso, como Bauer, segundo ele relata, passava a maior parte do tempo, dia e noite, a ler. Esse personagem, Delgado, um alter ego - às vezes, um alter ego ao avesso - de Carlos Bauer, ou do autor desse romance, ao falar de si mesmo, traça uma figura do leitor: como um "viajante que passa por uma paisagem que foi construída. E é infinita". Sempre os lugares..., e diz náo encontrar felicidade maior do que "percorrer em poucas horas diárias um tempo humano que, de outro modo, me seria alheio. Uma vida não é suficiente para percorrê-lo. Roubo metade de uma frase de Jorge Luis Borges: 'uma biblioteca é uma porta no tempo"” (DOMÍNGUEZ, 2006, p. 44-45). Não por acaso, o mesmo Borges, citado por Delgado, considerava que a origem da biblioteca e do tempo seriam “os mistérios básicos da humanidade” (BORGES, 1974, p. 468). 
$\mathrm{O}$ que temos aqui: a ideia de um tempo humano, cujo percurso, o trajeto da viagem, é garantido pelos livros no espaço da escrita, a qual esboça pela narratividade, tal como proposto por Ricoeur (1994, p. 15), os traços da experiência temporal. De fato, os livros são capazes de engendrar aproximaçóes do tempo, de escandi-lo, condensar milênios, séculos, nos limites de suas páginas, as quais podem ultrapassar, como assinala Delgado, o limite de uma vida. Por isso mesmo, eles podem ser, para nós, uma porta, repetindo Borges, de entrada para uma outra dimensáo da experiência do tempo pelos homens, ou melhor, pelos leitores. E o personagem Delgado, na linha de afinação com os desafios da percepção do tempo nos livros e na leitura, não esconde como isso é parte do poder de atração do livro e do seu fetiche para leitores e bibliófilos, como veremos mais adiante. Esse tempo concentrado do livro é bem a expressão de como a narrativa ficcional, histórica e/ou memorialística articula uma síntese para a diversidade temporal. Afinal, na narrativa, a figuração do tempo tecida nos textos coexiste com a refiguração do tempo que se dá também nos atos de leitura. ${ }^{6}$

Nas evocações de suas experiências e relaçóes com as bibliotecas e os livros feitas em seu livro L'amour des bibliothèques (GOULEMOT, 2006, p. 47), o historiador Jean-Marie Goulemot, por sua vez, recorre à representação da viagem e do viajante ao distinguir as novas relaçóes com o tempo e o espaço propiciadas pelas bibliotecas desde a grande Biblioteca de Alexandria: o tempo da acumulação, o tempo da leitura concebido como um diálogo entre o autor e o leitor, o tempo da difusão de textos vindos de outro lugar e pertencentes a outras culturas, modificando inclusive a relação com o espaço, o qual durante séculos teria sido conhecido apenas pelos viajantes e navegadores. A metáfora do viajante e também dos percalços nos caminhos da viagem é invocada, na teoria literária, por Antoine Compagnon, ${ }^{7}$ em descrição da leitura como "uma viagem através do texto", e nas descriçôes do leitor como possuidor, à moda dos viajantes, de "um ponto de vista móvel, errante, sobre o texto" (COMPAGNON, 2001, p. 152).

A passagem e o acesso à temporalidade de um mundo outro não escaparam às figurações e sensações de Walter Benjamin que, por seu turno, no célebre texto Desempacotando minha biblioteca. Um discurso sobre o colecionador (BENJAMIN, 1987), atribui ao livro essa capacidade de comunicação com o tempo, com o mundo do passado e também das recordaçóes. Ao falar dos colecionadores de livros como grandes fisiognomonistas do mundo dos objetos, diz que eles "se tornam intérpretes do destino" (BENJAMIN, 1987, p. 228). Isto porque todos os detalhes sobre os livros indicados por Benjamin - e que podemos ampliar aqui como elementos-chave da leitura contemporânea - tais como a origem, o antigo dono e suas marcas de uso e de leitura; a região, o local e a época da escrita ou da edição; a arte do livro, na cobertura e nas ilustraçôes "se somam para formar uma enciclopédia mágica, cuja

\footnotetext{
${ }^{6}$ Nesse alinhamento com o pensamento de Ricoeur e a ideia de um tempo concentrado tal como exploramos neste texto, ver o diálogo teórico desenvolvido em Tempo e narrativa, em especial em torno da mimesis e do muthos aristotélico, face ao tempo como distentio animi em Santo Agostinho (RICOEUR, 1994).

${ }^{7}$ Este autor se refere a Wolfgang Iser, na sua obra O leitor implícito. Ver Compagnon (2001).
} 
quintessência é o destino de seu objeto". Segundo Benjamin, para tal, "basta observar um colecionador manuseando os objetos em seu mostruário de vidro. Mal os segura nas mãos, parece inspirado a olhar através deles para seus passados remotos". E cita Habent sua fata libelli - os livros têm seu próprio destino. Assim, segundo ele, "livros como $A$ divina comédia ou a Ética, de Spinoza, ou a Origem das espécies têm seu destino. O colecionador, porém, interpreta esse aforismo latino de outro modo. Para ele não só os livros, mas também seus exemplares têm seu destino" (BENJAMIN, 1987, p. 229).

Esta é outra maneira de dizer que o livro e seus exemplares e ediçôes também possuem uma biografia, uma história sua, que se desenrola no tempo, e que é também uma história dos usos, das posses, dos leitores, das bibliotecas físicas, que também facultam um tipo de acesso ao tempo e à memória.

Mas, no livro A casa de papel, o misterioso Bauer, destinatário da dedicatória do livro de Joseph Conrad, vai tentar ser ele mesmo o dono do destino de seus livros, conforme conta o bibliófilo Delgado ao narrador desse livro.

\section{Carlos Bauer: paixão e desejo de um colecionador de livros}

No retrato que Delgado vai traçar de Bauer, outras tópicas mencionadas mais acima dão gradualmente forma ao personagem, conferem sentido à narrativa do autor desse romance, dão resposta ao mistério e, além disso, oferecem interessantes elementos metodológicos aos historiadores, em especial, aos historiadores do livro. Quem era, portanto, esse Carlos Bauer? Em primeiro lugar, um leitor compulsivo, incurável, cujo dinheiro era destinado à compra de livros, os quais abarrotavam a sua casa inteira, incluindo as escadas, a tal ponto que ele dormia em um sótão, e, no inverno e no verão, tomava duchas frias para evitar que os livros colocados nas prateleiras do banheiro fossem impregnados pela umidade, e, por conseguinte, ficassem estragados. ${ }^{8}$ Os exemplares de suas obras acabavam por tornar-se manuscritos, por causa de suas numerosas anotaçóes à margem feitas em várias cores, como sinal para conferir-lhes um sentido. Ao contrário dos exemplares de Delgado, o bibliófilo, que nunca deixava marcas nos livros e limitava-se a anotaçóes em pedaços de papel introduzidos nos volumes, consciente de que as indicaçóes são notas de um leitor e, como tal, podem levar a outros livros e a outras reflexôes, sem o risco de estragar os exemplares com o que designava serem os "garranchos" brutais de Bauer. Este, diferentemente de Delgado, afirmava a respeito de suas marcas: "Faço sexo com cada livro e se não houver marcas, não há orgasmo" (DOMÍNGUEZ, 2006, p. 45). E como ele durante muitos anos

\footnotetext{
${ }^{8} \mathrm{O}$ escritor Alberto Manguel também conta que, quando viveu no Canadá, tinha estantes de livros na cozinha e no banheiro, e os filhos diziam que precisavam de uma carteira de leitor de biblioteca para entrar em casa. Ver Manguel (2006, p. 64-65).
} 
dispôs de dinheiro para comprar qualquer livro que cobiçava, o seu desejo era, segundo a narrativa de Delgado, ilimitado, portanto, ele se tinha tornado um conquistador: náo de mulheres, mas de livros.

É nesse jogo em torno da posse e do desejo, considerado uma espécie de jogo passional, que se expressa o gosto pela coleção, o qual impele os colecionadores, secularmente, ao ato de colecionar. Já no século XVII, o Padre Antônio Vieira referia-se à coleção como uma coleção de tentaçôes: "cada uma das tentaçôes em singular é a que forma aquela coleção ou multidão de todas" (MORAES SILVA, 1813, p. 413). O termo tentação (MORAES SILVA, 1948, p. 757) se origina do latim tentare, que significa experimentar, provar, e, ao mesmo tempo, disposição de ânimo para a prática de coisas diferentes ou censuráveis. Essa força compulsiva pode ser nomeada como desejo, seja da posse, da descoberta, da acumulaçáo ou do agrupamento. Assim a etimologia da palavra tentação se póe de acordo com a ideia de que a disposição do colecionador advém de um desejo despertado pelo objeto, no caso em tela, pelos livros. Também o desejo impele à conservação do objeto no que diz respeito a tipos específicos de cuidado, posse e manutenção.

Aqui, é quase inevitável que nos venha à mente o livro do historiador Jean-Marie Goulemot, no já citado L'amour des bibliothèques. Nesse texto, ao fazer o relato íntimo de sua vida, ele confessa ter "passado mais tempo a ler em biblioteca que a comer, a frequentar os cinemas ou os museus, a tirar férias à beira mar. [...] Conheci, sem dúvida, um número maior de bibliotecas que de mulheres" (GOULEMOT, 2006, p. 19). ${ }^{9}$ E admite que os livros da sua biblioteca pessoal, que ele mesmo colecionou, podem não ter a mesma função e o mesmo estatuto dos que ele lê em outra biblioteca, mas mesmo assim "têm em comum a relação corporal, quase erótica, mantida entre eles" (p. 32) ${ }^{10}$. Daí ele raramente emprestar livros da sua biblioteca pessoal, uma vez que os livros que coleciona "não são feitos somente para serem lidos" - diferentemente dos de uma biblioteca pública, institucional, em que o livro é destinado especialmente à leitura. Haveria algo de fetiche, da ordem do desejo, do prazer dos sentidos, do lúdico e do estético na posse e na relação de um leitor/colecionador com sua biblioteca pessoal.

Falar das bibliotecas em geral, para Goulemot, é falar dos livros, dos leitores, dos lugares dedicados à leitura. Ele reage, em sua narrativa, ao fato de que as definiçóes de biblioteca, tais como encontradas nos dicionários, nunca utilizam a palavra leitura (GOULEMOT, 2006, p. 17). Esse não é o caso do livro $A$ casa de papel, na concepção que permeia os relatos sobre as bibliotecas pessoais de Bauer e de Delgado: antes de tudo, eles são grandes leitores!

\footnotetext{
${ }^{9}$ Tradução da autora. No original: “J'ai passé plus de temps à lire en bibliothèque qu’à manger, à fréquenter les cinémas ou les musées, à prendre enfin des vacances au bord de la mer. [...] J'ai sans nul doute connu plus des bibliothèques que des femmes".

${ }^{10}$ Tradução da autora. No original: "Ils ont en commun le rapport corporel, presque erotique, entretenu avec eux [...] Les livres que je collectionne ne sont pas faites seulement pour être lus”.
} 
Outro aspecto ainda autoriza uma aproximação entre o historiador Goulemot e o personagem Bauer: as marcas nos livros. Goulemot menciona a sua angústia quando, em um catálogo de livros usados, lê as palavras novo e/ou folhas não abertas e a indicação de um livro em estado impecável. O mesmo ocorre, em sua opinião, com "um livro que não foi apreciado como livro, que não foi devorado, como se diz, digerido também [...] conservado limpo e novo, torna-se um objeto de decoração ou especulação" (GOULEMOT, 2006, p. 16). ${ }^{11}$ Portanto, nessa linha, entendemos que um livro assim, conservado em tal estado, é tal como um objeto frio, sem a possibilidade do estimulante contato físico entre o livro e o leitor, sem os prazeres mobilizados pelo tato, pelo cheiro, pela visão, pela prazerosa sensação do rendimento da leitura no passar das páginas, sem a tensão ou a cumplicidade empática entre autor e leitor, e entre o leitor e realidade palpável do livro.

E é no contato corporal levado ao extremo que se encontra a chave para o desvendamento da história que envolve Bauer e o livro sujo de cimento enviado a Bluma, em $A$ casa de papel.

\section{Os imponderáveis do livro e seu contrário: abrigo, casa, lar}

Bauer, que sobrevivia de seu desejo e de seu amor pelas bibliotecas, comprava os livros em leilóes, segundo Delgado, de maneira voraz e sem escrúpulos. Sua biblioteca era a sua obra. Escutando Delgado, o narrador descobre que, no decorrer dos anos, Bauer tinha ficado sem um só vintém e, portanto, impossibilitado de comprar outros volumes, e sem espaço para os seus livros ameaçados pelas traças que se tinham instalado nas prateleiras, acabou sendo forçado a vender a casa e mudar de moradia. Soterrado pelos livros, à beira de um colapso mental e tendo decidido não se desfazer de sua obra, ou seja, de sua biblioteca, ele vai viver isolado em um lugar ermo à beira-mar, em uma praia deserta, local sem energia elétrica e sem água potável. Apenas ele e os livros.

Bauer, tal como relatado por Delgado, manda transportar para esse local todos os exemplares de sua biblioteca: e, juntando-os com areia e concreto, como que possuído pela loucura, vai transformá-los em tijolos para edificar a sua casa. Nesse enorme "corpo da letra impressa”, como em um terrível pesadelo, as páginas, os volumes, as ediçôes foram empilhados ao acaso para erguer as paredes atrás das quais ele encontrará abrigo do vento, do sol e do frio. Segundo o bibliófilo, a Delgado já

não lhe importavam mais a amizades e as inimizades entre os autores, as afinidades ou contradiçóes [...] se as encadernaçóes eram boas ou medíocres, se tinham gravuras ou lâmina, se as páginas ainda não estavam cortadas, ou se se tratava de incunábulos. Apenas a proporção

\footnotetext{
${ }^{11}$ Tradução da autora. No original: “Un livre qui n’a pas été aimé comme un livre, dévoré, comme l'on dit, digéré aussi, et qui, conservé si propre et si frais, est devenu un objet de décoration ou de spéculation”.
} 
de cada volume, a espessura, a firmeza de suas capas para resistir à argamassa de cal, cimento e areia (DOMÍNGUEZ, 2006, p. 70-71).

Assim é que, segundo o relato de Delgado, as obras de Virgílio, Aristóteles, Shakespeare, Espinosa, Kant, Kafka, Hemingway, Camus, Vargas Llosa, dentre tantos milhares de livros de autores do panteão literário e filosófico universal são daí em diante livros sem leitor, "livros que ninguém ia abrir, olhar com desejo". No caso dos livros de Bauer, eles se veem reduzidos à sua materialidade bruta, a um "resto orgânico", no dizer do narrador, portanto esvaziado e desincorporado das marcas dos "impressores, artistas, secretárias, tipógrafos, comentaristas, escritores, e mensageiros, operários de tinta e da encadernaçáo, ilustradores, prefaciadores, cultos críticos da memória” (DOMÍNGUEZ, 2006, p. 83) que lhe conformaram uma existência em consonância com uma finalidade.

$\mathrm{O}$ aspecto mais trágico da magnitude funesta desse acontecimento se aloca então no que já foi tão bem expressado por Goulemot quando diz: "Ora, sabemos que os livros que não são lidos deixam bem depressa de serem livros. Eles tornam-se algo diferente, e adquirem seu valor de outras qualidades que o interesse suscitado pela leitura" (GOULEMOT, 2006, p. 16) ${ }^{12}$.

Bauer como leitor, assim supomos, estava consciente disso. No entanto, é a figura alegórica de uma mulher, Bluma, que vai, literalmente, colocar abaixo o alucinado projeto de Bauer para sua nova moradia. Ao solicitar-lhe, por carta, o exemplar do livro de Conrad que ela lhe havia enviado como presente, Bluma, a pretexto de uma necessidade do livro para terminar sua tese sobre Conrad - o qual, segundo o narrador, teria, na realidade, servido para encobrir ou aniquilar a fantasia e o desejo irresolvidos, brotados de um encontro fugaz de ambos -, precipitou o fim do outro destino atribuído por Bauer a seus livros e à sua biblioteca. Os buracos abertos por Bauer nas paredes da sua casa de papel em busca do livro pedido por Bluma - finalmente encontrado e reencaminhado para a Inglaterra - acabaram por destruir o suposto equilíbrio de sua casa, derrubando-a na instabilidade do chão arenoso, apesar dos esforços de Bauer para evitar tal desfecho. Na realidade, a ruína da casa de papel havia começado antes da sua edificação, ou seja, no momento da quebra do que já foi chamado por Paul Valéry (2008, p. 83) da "conformidade quase miraculosa de um objeto com a função que deve desempenhar"13. Afinal, segundo entendemos, não se trata apenas da perda da função utilitária, do valor de uso do objeto, mas da perda da sua "aura”, ou seja, da sua dimensão de valor, verdadeira mitologia do objeto, responsável pela sua virtude e preciosidade, as quais atraem e apaixonam o colecionador, e que está na base dos traços que caracterizam o livro como "objeto de coleção".

\footnotetext{
${ }^{12}$ Tradução da autora. No original: “Or, nous savons que les livres qu'ont ne lit pas cessent assez vite d'être des livres. Ils deviennent quelque chose de différent et tirent leurs valeurs d'autres qualités que l'intérêt suscité par la lecture".

${ }^{13}$ Tradução da autora. No original: “[...] la conformité presque miraculeuse d'un objet avec la fonction qu’il doit remplir".
} 
Após o desmoronamento de sua casa, ao ver quebrada a possibilidade de uma vida isolada no interior do espectro de sua biblioteca, Carlos Bauer desaparece, e o narrador - o colega de Bluma, em Cambridge, que conservara o exemplar, sujo de concreto, do livro de Joseph Conrad e que havia acompanhado a história do que viria chamar de a "encarniçada viagem dos livros" (DOMÍNGUEZ, 2006, p. 86) - chega a termo com sua investigação. E apesar de desfeito o mistério em torno do livro, encontra na sua visita ao local da casa de papel de Bauer apenas os restos de um imenso cadáver de "letras de forma", misturado com areia, destroços e com os restos de ossos, originários da fauna marítima. Ou seja, dito de outro modo, o narrador do livro depara com a expressão da ruína, nesse caso como triunfo da natureza sobre a cultura. Bauer, onde quer que estivesse, não poderia mais dizer o que Delgado, em um momento do seu depoimento ao narrador, supôs que ele tivesse dito sobre os livros já na sua casa de papel: "Continuam sendo meus amigos. Eles me dão abrigo. Sombra no verão. Protegem-me dos ventos. Os livros são a minha casa” (DOMÍNGUEZ, 2006, p. 72-73).

A recorrente tópica do livro como um abrigo, ou casa, ou lar, aparece de maneira interessante e rica na sua diferença em Alberto Manguel, no seu livro A biblioteca à noite (2006), e também em Walter Benjamin (1987) no texto já citado. Para o primeiro, Manguel, é a sua leitura da Odisseia que lhe traz a imagem do lar. Dizendo que cada leitor lê uma Odisseia diferente, e suas leituras prolongam as aventuras de Ulisses bem além das Ilhas Afortunadas rumo à eternidade - o que nos reenvia às vidas dos livros, na sua circulação e nas suas várias recepções pelos seus leitores -, ele acrescenta que, de todas as histórias de Ulisses, nenhuma é mais comovente que a da chegada ao lar. Porque, segundo ele, nela se pode perceber

o mundo de dois modos diversos - como terra estrangeira ou como lar - e que as nossas bibliotecas refletem essas duas visóes opostas. Vagando entre nossos livros, [...] as páginas ou bem nos espantarão por diferir de nossa experiência, ou bem nos confortarão por sua semelhança (MANGUEL, 2006, p. 252).

A figura do lar aqui se compóe com a da viagem em tempos e espaços distintos e com a estabilidade possível, malgrado os imponderáveis do livro.

Em Walter Benjamin, essa tópica aparece como o abrigo da memória, quando ao desempacotar os livros em uma de suas mudanças, ou exílio, afirma que nele afloraram imagens, lembranças capazes de suportar o trabalho de memória. Lembranças das cidades, nas quais ele achou tanta coisa; de livros; de salas luxuosas e de subsolos mofentos repletos de livros; lembranças dos recintos onde os livros ficavam na sua toca de estudante em Munique ou do seu quarto em Berna; e, por fim, do seu quarto de criança donde se originaram os primeiros dentre os milhares de volumes que cumulativamente formaram sua biblioteca. E saúda, nesse seu escrito, a figura bem-aventurada do colecionador, e os sentimentos dele próprio, para quem 
a posse é a mais íntima relação que se pode ter com as coisas [ou seja, os livros]: não que elas estejam vivas dentro dele [o colecionador]: é ele que vive a partir delas. E assim, erigi diante de vocês uma de suas moradas, cujos tijolos são feitos de livros, e agora, como convém, ele vai desaparecer dentro dela (BENJAMIN, 1987, p. 235).

Parece o personagem Bauer falando, uma vez dispensada a tópica da loucura.

\section{Os avatares da ordem e da desordem dos livros}

Deve-se sublinhar que, no livro $A$ casa de papel, a tópica do perigo representado pelos livros não é somente associada às tópicas do desejo e da paixão experimentadas no limite, levando a desvarios, à possível loucura, mas também à tópica da ordem e ao corpo material do livro. O que era, aliás, uma obsessão dos dois bibliófilos desse livro: Delgado e Carlos Bauer. No relato ao narrador, Delgado conta que Bauer, diante da grandeza de sua biblioteca, vivia angustiado com as dificuldades de localização de seus livros e, a partir de determinado momento, decidiu dedicar-se a seu fichário (DOMÍNGUEZ, 2006, p. 51-53). E Delgado acrescenta: "Um livro não encontrado é um livro inexistente". Bauer e ele tiveram, não obstante, problemas para chegarem a um acordo em relação ao melhor método de classificação, o qual entendia possuir um significado que não se restringia aos números atribuídos como instrumento de identificação. Para Delgado, classificar exigia um respeito estrito à ordem e, mais que os números, impunha-se adicionar o título, o autor, além de um breve resumo. Em sua opinião, a biblioteca de Bauer precisava disso porque "um homem pode conquistar várias leituras, mas um conquistador está obrigado a administrá-las”. Bauer, em compensação, teria optado pela busca das afinidades como princípio de organização. Na busca do que acreditava ser a ordem real das afinidades se opôs ao fichário temático, prática por ele designada de "vulgaridade temática". Ele apostava as suas fichas nas afinidades de toda a espécie, incluindo o valor literário e o das amizades, assim como as rivalidades entre os autores do livro. Portanto, ele se recusava a colocar lado a lado, conforme narra e explica Delgado, Garcia Lorca e Borges, dado a um suposto desdém do segundo pelo primeiro; Vargas Llosa e Gabriel García Marquez, certamente por certas incompatibilidades políticas; Shakespeare e Marlowe, dadas as insinuaçóes recíprocas de plagiato, entre outros. Essa busca das afinidades temáticas teria acabado, segundo o bibliófilo Delgado, por se tornar incontrolável. Nesse dilema obsessivo do encontro e da falta das afinidades, o bibliófilo Delgado detectou os primeiros sinais de uma “alteração mental” em Bauer.

A percepção de uma tensão como algo inerente às operações de escolha de compatibilidades entre os livros para fins de sua ordenação é assinalada, por exemplo, por Goulemot, para quem 
Em qualquer coleção privada, há uma classificação e uma desordem. [...] Meus livros antigos, em duas filas, passam por frequentes deslocamentos. Segundo o tamanho, o tema, a época, a série, os motivos da encadernação... Minha ação depende mais ou menos de minha fantasia e do ritmo imposto por minhas compras e descobertas. Não tenho catálogo, apesar de ter adquirido a consciência de que eu teria necessidade de elaborar um (GOULEMOT, 2006, p. 33). ${ }^{14}$

Já no sistema classificatório do personagem Bauer, ele não rejeitou a ajuda de um catálogo, nem da matemática. Ao contrário, tentou criar uma estrutura complexa de números fractais para adaptar as filas das obras em face dos intercâmbios no domínio das afinidades e, desse modo, encontrar facilmente os livros. Tais afinidades foram responsáveis também por seu hábito de ler os livros do século XIX à luz de velas e candelabros. Suas estratégias classificatórias, adicionadas a todos os seus problemas, levaram-no à beira de um colapso mental quando ocorreu o pior: um incêndio que queimou o seu fichário. Segundo o narrador, numa belíssima imagem, a simples "menção da palavra fogo diante de um bibliófilo tem o efeito da incineração de um sonho" (DOMÍNGUEZ, 2006, p. 62).

Nessa linha das aproximaçóes que vimos realizando, vamos encontrar Ricardo Piglia, em seu livro intitulado $O$ último leitor (2006), falando das relaçóes de Borges com os próprios livros. E Piglia nos diz que a metáfora do incêndio da biblioteca era muitas vezes nos livros desse autor "uma ilusão noturna e um alívio impossível" (PIGLIA, 2006, p. 27), pois, na biblioteca figurada por Borges, o imaginário segue instalado entre os livros, que continuam perdidos nos corredores, e os leitores seguem extraviados em meio aos volumes acumulados no fantástico espaço chamado biblioteca. Também Goulemot, por seu lado, lembra-nos que, desde o incêndio da Biblioteca de Alexandria - o qual nos faria lembrar, segundo ele, da condição frágil e mortal das bibliotecas - "o fogo é uma das formas privilegiadas do pesadelo da exterminação cultural" (GOULEMOT, 2006, p. 37). ${ }^{15}$ Essa afirmação, contudo, não impediu esse autor de uma nota de otimismo, pois, tal como bem ressalta, a memória da leitura pode assegurar que os livros continuem ainda a viver mesmo depois de destruídos. A imagem violenta e chocante da destruição de bibliotecas pelo fogo remete-nos também ao célebre Auto de fé (1991), de Elias Canetti, e ao final trágico dos tormentos do personagem Petert Kien, um professor e sinólogo erudito, e de sua obsessão pela posse dos livros. E não é por mero acaso que esse tipo de incidente, um incêndio, encontre também o seu lugar no relato da história de Bauer, o bibliófilo e leitor apaixonado. A perda das referências da locali-

${ }^{14}$ Tradução da autora. No original: "Dans toute collection privée, il y a un classement et un désordre. [...] Mes livres anciens sur des rangs subissent de très fréquents déplacements. Selon la taille, le thème, l'époque, la série, les motifs de la reliure... [...] J'ai agis plus ou moins à ma fantaisie et au rythme que m’imposent mes achats et mes trouvailles. Je n'ai point de catalogue, malgré la conscience que j’ai acquise qu'il faudrait en dresser un".

${ }^{15}$ Tradução da autora. No original: "[...] le feu est une des formes privilégiées du cauchemar de l'anéantissement culturel". 
zação de seus livros e da "ilusão de organizar a sua biblioteca" é o que o levou, finalmente, a dirigir-se à praia e a edificar a sua casa de papel, valendo-se de uma taxinomia que se torna irreconhecível para o amigo bibliófilo, na nova disposição que selará um destino fatal aos seus livros.

No tocante a essa tópica, outra referência se impóe: aquela relativa a Alberto Manguel e a seu livro já citado, $A$ biblioteca à noite, ${ }^{16}$ a ordem como uma classificação aparentemente lógica que ele define como "uma geografia que obedece a um sumário prévio e a uma hierarquia memorizável das letras e dos números" (MANGUEL, 2006, p. 20).

Ele se refere a uma ordem flexível submetida às reorganizações em relação à língua, aos autores, à ordem alfabética, ao tamanho dos volumes, aos assuntos, à cor, ao grau da afeição, sublinhando que uma biblioteca privada - semelhante à sua e à de muitas pessoas - permite elaborar "classificaçóes caprichosas e altamente pessoais" (p. 42). E, no seu caso, confessa ele, a ordem do catálogo é, à noite, convencional porque a atmosfera da noite restaura o caos e, na madrugada, "um livro chama inesperadamente por outro, criando alianças entre séculos e culturas diferentes" (p. 20). Portanto, propiciando aproximaçóes entre tempos distintos, Manguel sublinha ainda que, à noite, ele se torna um fantasma na sua biblioteca ${ }^{17}$, enquanto os livros são a única presença real. De fato, o caos está sempre aí, uma ameaça latente ao desejo de classificar tudo, tal como havia sido experimentado pelo personagem Bauer. Como nos lembra Walter Benjamin, "toda paixão se avizinha do caos", mas, segundo ele, a do colecionador de livros, às voltas com a tensão dialética entre a ordem e a desordem, "se aproxima da lembrança”. O que se sugere aqui é que também a desordem pode ser construtiva no trabalho de memória. A desordem habitual de seus livros seria a expressão "do acaso e do destino" que tingiriam "o passado diante de seus olhos". E admite que, "se há uma contrapartida para a desordem de uma biblioteca, esta seria a colocação em ordem de seu catálogo" (BENJAMIN, 1987, p. 228).

Afinal, como nos lembra Marco Lucchesi no seu livro O bibliotecário do Imperador (2013), em que a persistente pesquisa de fontes se mistura à liberdade da ficção na busca da vida de Inácio Augusto Raposo, personagem de carne e osso, bibliotecário de D. Pedro II, "o homem de livros é guiado pela fome do catálogo que é, ao mesmo tempo, estômago e mapa-múndi” (LUCCHESI, 2013, p. 29). No seu desenho mental, imaginário, da biblio-

\footnotetext{
${ }^{16}$ No qual ele reservou um capítulo inteiro à ordem (MANGUEL, 2006, p. 39-62).

${ }^{17}$ As tópicas da ordem e do fantasma transfiguram-se em significante em outro livro de ficção, bastante delicado, o de Penélope Fitzgerald, A livraria (2000). Trata-se de um romance sutil sobre a história de uma mulher inglesa que decide abrir uma livraria - em uma casa velha, habitada por fantasmas - e uma biblioteca itinerante localizadas em uma pequena cidadezinha do interior da Inglaterra. Às voltas com as encomendas, com o estoque e a organização dos livros, sua iniciativa vai enfrentar a oposição de alguns habitantes, a qual é fortalecida, entre outros pretextos, por sua decisão de colocar à venda Lolita, o sulfuroso romance de Vladimir Nabokov. A ordem, a classificação dos livros e a presença de personagens reais e ficcionais e populaçóes inteiras de fantasmas nas bibliotecas são também tratadas com espírito e erudição no livro de Jacques Bonnet, Des bibliothèques pleines de fantômes (Bibliotecas repletas de fantasmas) (2008).
} 
teca desaparecida do Imperador, um sentimento de posse legítima avulta na arrumação, na ordem daquela biblioteca

na boa relação dos volumes com seus pares, na montagem de um relevo harmoniosamente disposto, no balanço da altura ou da língua em que foram escritos, no desenho das capas, de acordo com o assunto, gênero, país, como se cada qual houvesse nascido para ocupar aquele espaço e nenhum outro além daquele em que se encontra, submisso a um destino irrevogável. Como se inaugurassem novo tempo e espaço, apagando o nome do antigo rei, como faziam os faraós (LUCCHESI, 2013, p. 54).

Tal como na concepção de ordem do bibliófilo Delgado.

Mas é, com efeito, a crença na capacidade indutora da desordem, no que concerne aos livros, que Benjamin nos lembra que "não há nenhuma biblioteca viva que não abrigue, em forma de livros, um número de criaturas das regióes fronteiriças" (BENJAMIN, 1987, p. 234), vivendo no que ele chama de "orlas prismáticas de uma biblioteca”. Não são fantasmas, mas podem ser, prossegue Benjamin, álbuns de colar ou de família, cadernos de autógrafos ou textos religiosos, folhetos, prospectos a que as pessoas se afeiçoam, manuscritos ou cópias datilografadas de livros impossíveis de achar, e revistas. Interessa-nos reter aqui é que junto aos seres habitantes dessas orlas prismáticas se escondem chaves históricas preciosas de acesso à arqueologia dos usos dos livros e das práticas de leitura e da vida dos livros como objetos. Essas podem ser, tal como sugere Lucchesi, "brasões, ex-libris, comentários a latere, com letra miúda, retratos escondidos e cartas que jamais chegaráo ao destino, fechadas no claustro de papel a que foram relegadas suas vidas, à revelia de si mesmas” (p. 54). Pode ser que na reconstituição de seus usos e na sua aparente desordem sobreviva a utopia de "algo parecido com uma ordem perfeita ou a caminho da perfeição" vislumbrada pela personagem do livro de Sebald (2010) quando confrontada com a condição de desordem do seu escritório, dos seus livros e papéis.

\section{Os possíveis do duplo}

Ora, a evocação dos fantasmas, muito frequente em ensaios e livros de ficção, pode perfeitamente conduzir-nos à tópica do duplo ${ }^{18}$. Esta nos fornece a ideia de uma ligação, de um

\footnotetext{
${ }^{18}$ Segundo Freud, ao tratar desse fenômeno - o que faz a partir da noção de "estranho" advinda da leitura do conto "O homem de areia", de A.T.A. Hoffmann - fala de personagens que parecem "semelhantes, iguais [...] de modo que um possuiu conhecimento, sentimentos e experiências em comum com o outro", possibilitadas por mecanismos de "duplicação, divisão, intercâmbio do eu". Ele também nos lembra das "ligaçóes que o duplo tem com reflexos em espelhos, com sombras, com os espíritos guardiōes, com a crença na alma e com o medo da morte", as quais conformam e tensionam algumas tópicas exploradas neste texto (FREUD, 1976 [1919], p. 293).
} 
"outro", que é a replicação do mesmo, grudado ao leitor e ao escritor. A imagem do duplo como expressão de uma união ambígua já se fazia presente, séculos atrás, em Montaigne ${ }^{19}$, nos seus Ensaios, em que fala dele e de seu livro como se ambos caminhassem juntos e de forma semelhante, dizendo: "Aqui, vamos conformes e no mesmo passo, meu livro e eu. [...] quem toca em um toca no outro" (MONTAIGNE, 2000-2001b, p. 29), ou ao afirmar:

Ao modelar sobre mim essa figura, tantas vezes tive que me ajustar e me compor para transcrever-me, que o molde se consolidou e de certa maneira formou a si mesmo. Ao pintarme para outrem, pintei em mim cores mais nítidas do que eram as minhas primeiras. Não fiz meu livro mais do que meu livro me fez, livro consubstancial a seu autor, com uma ocupação própria, parte de minha vida; não com uma ocupação e uma finalidade terceiras e alheias, como todos os outros livros (MONTAIGNE, 2000-2001a, p. 498).

Ora, a afirmação "fez-me o meu livro mais do que eu o fiz" sugere-nos a imagem do duplo como imagem inequívoca de uma comunhão inevitável do autor e do livro, seja porquanto lugar da própria configuração do sujeito, seja por uma identificação conflituosa, no sentido freudiano "de tal forma que fica em dúvida sobre quem é o eu, ou substitui seu próprio eu por um estranho" (FREUD, 1976, p. 293). Mas a imagem do duplo pode ser também estendida a outras relaçóes entre leitores e livros, tal como feito por Walter Benjamin, para quem "o destino mais importante de todo exemplar é o encontro com ele, o colecionador, com sua própria coleção" (1987, p. 229). O duplo nesses casos é indício de um tipo de relação bastante particular de identidade, legitimidade, autoridade entre o autor e sua obra, o leitor e os livros, e que não se restringe a um tipo de relação comum nas alegorias do duplo, a exemplo das relaçóes fixas entre o original e a réplica, mera repetição. $\mathrm{O}$ duplo, segundo entendemos, porta uma capacidade, ou abertura, para a criação. ${ }^{20}$

A imagem do duplo se presta também à análise das ligaçôes entre a literatura e a realidade, e entre a vida e o ato de leitura como é o caso no romance $O$ último leitor (2005), de David Toscana, cuja história se passa no México: em uma pequena aldeia e em meio à fome, à seca e à violência, um homem, que gostava de ler, vive através dos personagens dos livros da biblioteca da qual ele é o guardião e que tinha sido fechada pelo Estado pela simples razão de não ter um número suficiente de leitores. E será lendo e mergulhando no universo dos livros dessa biblioteca, frente a um mundo hostil, repleto de misérias materiais e humanas, que ele se póe a esperar o momento de seguir o destino trágico que um autor - afinal, ele próprio - lhe teria reservado nas páginas de um livro no prelo, intitulado $O$ último leitor. Isto porque ele não consegue separar o seu "ser" de "outrem”. E as histórias e os personagens dos

\footnotetext{
${ }^{19}$ Pela sugestáo de incorporaçáo de Montaigne fica aqui um agradecimento à amiga Telma Birchal. Sobre a questão do sujeito em Montaigne, ver Birchal (2007).

${ }^{20}$ Tal como a mimese que, segundo Ricoeur (1994, p. 60), não é só cópia do idêntico.
} 
livros que lê de forma vicária permitem-lhe estabelecer uma relação imaginária e ativa com a realidade que o anula, mas que sonha em modificar. Enfim uma história de encontros entre $\mathrm{o}$ ato de ler e a ação política.

Como nos lembra também Ricardo Piglia - de novo, em seu livro de ensaios, chamado igualmente $O$ último leitor - ao falar do ato de leitura nos textos de Jorge Luis Borges: "A leitura constrói um espaço entre o imaginário e o real, suprime a oposição clássica entre a ilusão e a realidade. Não existe simultaneidade mais real e mais ilusória que o ato de ler" (PIGLIA, 2006, p. 29). Nesse espaço, em nossa opinião, o duplo também acaba por se instalar. Pois, entre o imaginário e o real, encontra-se, como admite Piglia, o ponto de cruzamento entre o sonho e a vigília, a vida e a morte, o real e a ilusão e, acrescentaríamos nós, entre os cruzamentos entre o tempo de ontem, de hoje e do futuro.

E se sairmos do plano ficcional do livro de David Toscana, é possível pensar também nas formas de "transaçóes entre as obras e o mundo social", as quais, segundo Roger Chartier (2016, p. 16) $)^{21}$, se concentrariam, particularmente, em "relações múltiplas, móveis, instáveis entre a obra e suas diversas encarnaçóes", ou seja, na materialidade das diferentes ediçóes, inscritas em temporalidades diversas, marcadas por necessidades e interesses distintos que propiciarão leituras e apropriaçôes com incidências históricas decisivas sobre o destino dos textos.

E, voltando ao plano ficcional, o romance pode construir as suas histórias porque há ainda, segundo Piglia, um duplo vínculo entre "a leitura e o real, e entre a leitura e os sonhos". E continua, nos lembrando que o romance - com Joyce, Cervantes e outros - "procura seus temas na realidade, mas encontra nos sonhos o modo de ler" (PIGLIA, 2006, p. 23). Justamente a cultura da leitura e das práticas de leitura é o que nos autoriza, aqui neste texto, a buscar a história, em especial a dos livros, na literatura ${ }^{22}$, com sua percepção da realidade da existência e suas dimensóes criativas da experiência e da coexistência temporais.

Entretanto, o universo ficcional pode também separar a realidade do escritor e a realidade dos autores. Esse é efetivamente o caso do livro $O$ último livro (2012), de Zorán Zivkovic, um romance que é um misto dos gêneros policial e ciência ficção, em que o personagem principal da trama é um detetive bibliófilo que tem um diploma de literatura. Além disso, acreditava que as suas duas realidades, a do escritor e a do livro, eram de tal modo próximas uma da outra que poderiam produzir o aniquilamento sob a forma da morte. Que é o que acontece na obra. O objetivo da investigação do detetive consistia em encontrar a causa da morte de vários

\footnotetext{
${ }^{21}$ Tradução do autora. No original: “[...] the transactions between the works and the social world [...]. They mainly concern the multiple, mobile, unstable relations between the work and its multiples appropriations and incarnations".

${ }^{22}$ Foge aos limites deste artigo a entrada no grande debate envolvendo semiólogos, filósofos, teóricos da literatura e historiadores em torno do tema das relaçóes entre história e literatura, especialmente à luz das contribuições advindas do pós-estruturalismo. Entretanto, cabe assinalar uma discussão recente e inspiradora sobre o tema, com as cores de um manifesto pelas ciências sociais, que se soma às exploraçóes já clássicas abrindo outras trilhas de questionamentos, e que pode ser encontrada em Jablonka (2016).
} 
leitores de um mesmo livro em uma livraria, e todas essas mortes tiveram como móbil a figura do duplo: o escritor detetive e o detetive escritor são uma mesma pessoa, "mais do que gêmeos idênticos" (ZIVKOVIC, 2012, p. 232). A leitura do livro, do gênero policial, é que provocou na trama a morte dos leitores, justo quando a realidade do escritor e a do livro se cruzaram implodindo os limites entre a realidade do escritor detetive e do detetive escritor da ficção, entrelaçando o autor e o seu personagem. A morte através da leitura, tal como expressado pelo escritor-detetive - que afirmava não ter querido imitar $O$ nome da rosa, de Umberto Eco -, foi usada como um artifício para a afirmação do "gênero" literatura policial e sua reputação como "uma leitura séria", não "leve", ou seja, massificada, uma vez que "na literatura séria, as pessoas também morrem. Às vezes, muito mais" (ZIVKOVIC, 2012, p. 234).

$\mathrm{Na}$ literatura policial, quando os livros e as bibliotecas são o tema preferencial, as tópicas do duplo e da morte aparecem comumente associadas não raro em torno da figura do detetive $^{23}$ de homicídios, do detetive bibliófilo e/ou detetive escritor, o corretor de provas e/ou o investigador, o espião, que atuam em tramas articuladas às bibliotecas e livros que podem ser mortais, a assassinatos de bibliotecários e proprietários de livros, a livros desaparecidos, às disputas e artimanhas dos alfarrabistas no mundo comercial dos livros, ao fetiche material dos livros e das raridades bibliográficas e cobiçadas primeiras ediçóes que nutrem crimes e ilegalidades de todo tipo. ${ }^{24} \mathrm{O}$ tipo detetive e seu duplo bibliófilo e/ou escritor parece feito à medida para assegurar o acesso à chave do mistério das histórias, bem como sobre o papel do livro, da escrita da investigação, qual seja, conduzir o leitor à noção da "descoberta" que só a leitura propiciaria em diferentes domínios. Afinal, essa noção responde pela aproximação do sujeito desse gênero literário, no caso o detetive, com o sujeito do conhecimento na história - também na antropologia - em que ambos exercitam as faculdades da lógica e da imaginação na busca e leitura de pistas, indícios, sinais, através das quais buscam ligaçóes nem sempre aparentes e inequívocas, e tentam estabelecer conexóes de sentido entre fragmentos, ausências, silêncios e repetiçôes. ${ }^{25}$

${ }^{23}$ A figura do detetive surge na obra de Edgar Allan Poe - considerado o inventor do romance policial mo-
derno, em Histórias extraordinárias - mais precisamente com a figura de Auguste Dupin, no célebre conto "O
duplo assassinato na Rua Morgue" (POE, 1966, p. 85-126). Um praticante do gênero, o argentino Rodolfo
Walsh, no entanto, sustentava que "todos os elementos essenciais do gênero se encontram dispersos na lite-
ratura de épocas anteriores, inclusive em textos bíblicos", embora admitisse que Zadig, de Voltaire, seria o
texto mais próximo à literatura policial moderna tal como em Poe, Doyle, Dickens e outros. Ver: "Dois mil
e quinhentos anos de literatura policial" (WALSH, 2011, p. 221). Acrescentaríamos que, nesse debate, não
se pode ignorar o livro de E. T. A. Hoffmann, A senhorita de Scuderi ([1820] 2012). Um belo texto sobre o
gênero policial é "Leitores imaginários", de Ricardo Piglia (2006, p. 74-97).
${ }^{24}$ Este é o caso emblemático de títulos tais como Ediçôes perigosas; O último caso da colecionadora de livros;
A promessa do livreiro; Impressóes e provas; e Assinaturas e assassinatos, do escritor americano John Dunning
Também de Variaçóes em vermelho, do escritor argentino Rodolfo Walsh; de Máscaras, do cubano Leonardo
Padura Fuentes; e do livro O ladráo que estudava Espinosa, do escritor, também americano, Lawrence Block,
em que um livreiro é ao mesmo tempo um ladráo de cofres, num típico exemplo do uso da figura do duplo,
entre outros.
25 As conjecturas a partir da leitura de pistas, indícios e sinais aproximariam, através do uso comum do méto- 
Essa tópica do duplo compóe-se simultaneamente àquela do corpo material do livro. Então, voltando ao surpreendente livro $A$ casa de papel, é impossível evitar a evocação de Donald F. McKenzie (1991) e a sua contribuição decisiva para a sociologia dos textos, para a crítica textual, para a bibliografia e para a história dos livros, da leitura e da edição, quando se procede, na mencionada obra ficcional, à encenação da materialidade dos livros. A esse propósito, os diálogos entre Delgado, um leitor ficcional, e o narrador do livro $A$ casa de papel são notáveis, e essas tópicas promovem um reencontro com a força exploratória da materialidade dos suportes e de sua riqueza, fazendo brotar outras instâncias para sua legitimidade arqueológica. De acordo com Delgado, em determinados livros, a página é um formidável desenho:

Um jogo de linhas e de figurinhas que se repetem, de vogais e consoantes, com as suas próprias leis de ritmo e de composição, sem que nunca o corpo, a letra escolhida, o espaço das margens, a densidade do papel, a numeraçáo, seja à direita ou ao centro, permaneçam indiferentes (DOMÍNGUEZ, 2006, p. 58-59).

Em um livro, ele mostra ao narrador que existem ruas verticais, diagonais desenhadas pelas separaçóes entre as palavras. Ele relata o fato de ter encontrado, em alguns livros, ruas compridas que se prolongavam de uma linha à outra, que haviam cruzado os parágrafos, às vezes interrompiam-se e retomavam um trajeto diagonal, da direita para a esquerda e da esquerda para a direita, ou em queda livre. Segundo Delgado, essas disposiçôes e composição de movimentos e formas seriam fundamentais para se captar o ritmo e se alcançar a hierarquia do estilo do escritor. Portanto, serviriam para a compreensão da produção de sentido do texto. Nessas descrições, é interessante perseguir as afinidades entre o leitor ficcional, Delgado, e as liçôes da materialidade das palavras escritas e dos suportes da interpretação dadas por McKenzie, que não negligenciou as imagens, tampouco as convençôes tipográficas colocadas no texto pelo editor, pelo impressor, ciente, segundo suas próprias palavras, de que "as formas têm um efeito sobre o sentido" (MCKENZIE, 1991, p. 30). ${ }^{26}$

do indiciário da semiótica médica - na opinião de Carlo Ginzburg - a figura moderna do detetive da literatura policial e os historiadores. Segundo esse autor, o manuseio do paradigma indiciário foi o elemento-chave da identidade de Sherlock Holmes, na sua criação por Conan Doyle, o qual era médico de formação. Na demonstração dessas suas hipóteses, Ginzburg se remete também a Sigmund Freud, ao método da psicanálise e à tomada dos indícios como sintomas, e ao historiador da arte Giovanni Morelli. Ambos também médicos. Sobre essa "tríade", como designa o autor, e a relação das pistas com o método científico, ver Ginzburg (1989, p. 143-179).

${ }^{26}$ Tradução da autora. No original: “[...] les formes ont un effet sur le sens”. Aliás, esse legado de Mckenzie tem sido bastante explorado pela historiografia, especialmente pelo uso exemplar e inspirador realizado por Roger Chartier em seus inúmeros estudos, a propósito das formas e dos suportes da leitura, entre outros, em Chartier (2014). No que toca à figura do editor, vale a pena lembrar o conceito de ato, ou gesto, editorial, que, na feliz denominaçáo de Brigitte Ouvry-Vial, torna o editor um duplo do leitor e um duplo do autor. O editor aparece "dotado de um poder e de uma vontade" (OUVRY-VIAL, 2007, p. 67-82). 
Ítalo Calvino deixou-nos também páginas formidáveis sobre a materialidade dos livros ao servir-se dos leitores de romances e de suas respectivas práticas de leitura como personagens e tema principal do seu livro Se um viajante em uma noite de inverno (1999) - de novo, o leitor viajante. Nesse texto, a intriga é armada em torno de um erro de impressão ocorrido no processo de encadernação, o qual redundou em páginas repetidas e na busca da edição completa, jamais encontrada. Nele, os romances lidos por seus personagens/leitores estão todos inacabados, a leitura dos livros não se finaliza jamais, as narrativas são inconclusas e fragmentadas, a memória fica em suspenso.

Por meio desse livro, Calvino aborda o ato da leitura, entre outros, pelo percurso realizado pela máo do leitor, pelo toque dos dedos na capa e na contracapa em visita aos recantos do livro, assinalando a importância de ler o que está fora antes de ler o que está dentro. Sem esse procedimento prévio, o leitor, em sua opiniáo, encontra-se despreparado para reconhecer o estilo do autor e o sentido do texto. Essa experiência corpórea seria, sugere-nos o autor, parte integrante tanto do gosto da leitura quanto do gosto na leitura, e se somaria ao sabor destilado pela sonoridade das palavras e pela grafia destas ${ }^{27}$. No caso das páginas coladas incidentalmente, ele se refere ao prazer tátil, visual e mental da espátula, bem como ao gesto que permite atravessar a consistência material do livro para dar acesso ao seu segredo e à sua substância incorporal, não física. ${ }^{28} \mathrm{Em}$ um diálogo, pela boca de um de seus personagens, ele diz: "ler é sempre isto: existe algo que está aí, uma coisa feita de escritura, um objeto sólido material [...] e por meio dele nos defrontamos com algo que não está presente e faz parte do mundo imaterial, invisível, porque é apenas concebível, imaginável ou porque existiu e não existe mais [...]". Ao que, retruca sua interlocutora, que "ler talvez seja ir ao encontro de algo que está para ser e ninguém sabe ainda o que será” (CALVINO, 1999, p. 78).

E Calvino não passa ao largo das práticas de leitura silenciosa ou em voz alta, em que os encontros entre o ritmo, a atenção e a condição palpável do texto se mostram de formas diversas quando a leitura deixa de ser feita em silêncio para ser realizada por outro. Em meio a todos esses movimentos implicados na leitura - e nesses encontros das interrogaçóes da literatura com as grades analíticas da história - emerge o poder do leitor, o único, segundo o autor, capaz de ter uma relaçáo privilegiada com o livro expressa no poder de considerar "aquilo que é escrito algo acabado e definitivo, ao qual nada pode ser acrescentado nem suprimido (CALVINO, 1999, p. 119). E emerge também um outro imponderável da recepção, qual seja, o fato de que, de alguma maneira, "o livro se deixa ler, independentemente daquilo que você esperava do autor” (p. 17) e não só independentemente do que esperava o autor mesmo dos seus leitores presumidos.

\footnotetext{
${ }^{27}$ Sobre esse tipo de relaçáo com os livros, tratada na forma ficcional, é interessante o livro do escritor espanhol Fernando Trias De Bes, Tinta (2013). Em uma espécie de ode aos tipógrafos, revisores, editores, enfim, ao livro impresso, ele faz das palavras e da tinta o cerne de uma alegoria da sedução perturbadora dos livros. ${ }^{28}$ Sobre as descriçóes minuciosas feitas pelo autor a respeito do uso da espátula, ver Calvino (1999, p. 48).
} 
$\mathrm{Na}$ descontinuidade das histórias desse livro o autor constrói uma história em que "cada romance iniciado e interrompido correspondia a um caminho descartado" e o livro, como ele mesmo admite, poderia ser uma espécie de autobiografia negativa, ou seja, os romances que ele poderia ter escrito e descartou. Esse sentimento de estar vivendo em um tempo em que as grandes narrativas e o verdadeiro romance se esfacelaram em fragmentos, fazendo com que a única verdade fosse a do instante vivido, levou Calvino a acreditar que a memória, se verdadeira, só poderia sobreviver enquanto não fosse encerrada em uma forma, por exemplo, a do livro (p. 185)

\section{Considerações finais}

À guisa de conclusão, gostaríamos de enfatizar que essas várias tópicas sobre o livro, abrigadas no interior de escritos tais como o acadêmico, o ficcional, o ensaístico e o memorial se relacionam ao lugar que as representaçóes acerca dos livros, da leitura, dos leitores, das bibliotecas e dos editores ocupam no imaginário intelectual e na memória cultural do Ocidente, e na construção de certos cânones literários e historiográficos. A literatura e os literatos, assim como os memorialistas e os ensaístas têm escrito, como já sabido, páginas importantes para a história do livro, da edição e da leitura. Afinal, a imaginaçáo literária, a imaginação histórica, bem como o exercício ensaístico e o esforço memorialístico, igualmente inventivos, nutrem-se mutuamente, seja no plano das ideias, seja no da riqueza especulativa. E a escrita histórica e a escrita literária fluem na direção do que já foi chamado de "articulação entre coerência narrativa e conexão explicativa" (RICOEUR, 2000, p. 314). ${ }^{30}$ À sua maneira, esses escritos, ao tomarem o livro como objeto de análise, matéria de ficção, exercício de memória, sustentam a cultura do livro e uma espécie de mitologia em torno do poder do livro, a qual, não sem desencontros, ganhou força enquanto um constructo performático poderoso da modernidade e do ideal civilizatório profundamente enraizado na realidade e no imaginário do Ocidente.

A dimensão teleológica, por um lado, tal como foi definida por Borges, explicitada na frase de Mallarmé (apud BORGES, 1974, p. 91) - "O mundo existe para culminar em um

\footnotetext{
${ }^{29}$ Em outro livro, As cidades invisiveis (1990, p. 82), Calvino nos diz que as margens da memória se cancelam quando fixadas pelas palavras. A trama de Se um viajante em uma noite de inverno convida-nos, portanto, a pensar o tempo, mas não o trabalho de memória. Esta, em Calvino, parece-nos ficar confinada em um passado que o presente poderia anular e invalidar. Fica distante, assim, da rica sugestáo da Rainha Branca a Alice, em Através do espelho e o que Alice encontrou lá, de Lewis Carroll, de que "é mísera a memória que só funciona para trás. Viver às avessas teria uma grande vantagem”, segundo a Rainha, pois “a memória funciona nos dois sentidos". Alice replica: "tenho certeza de que a minha só funciona em um. Não posso me lembrar de coisas antes que elas acontecessem" (CARROLL, 2009, p. 224).

${ }^{30}$ Tradução da autora. No original: "L'articulation entre la cohérence narrative et connexité explicative".
} 
livro"31 -; de outro, o peso do determinismo, paralisante da ação, diríamos, tal como encontrado em Dostoievski, quando em Crime e Castigo Raskólnikov, ao decidir entregar-se à polícia, diz: "E para que viver depois disso, para onde estou me dirigindo neste momento, quando eu mesmo sei que tudo vai ser exatamente como está nos livros e náo de modo diferente?" (DOSTOIEVSKI, 2009, p. 528); ou em Borges, sempre enredado entre livros, e que fala dentre as estantes da biblioteca que "a certeza de que tudo está escrito nos anula e nos transforma em fantasmas" (BORGES, 1974, p. 410), mostram-nos a amplitude e a profundidade do lugar reservado aos livros e à leitura na tradição cultural do mundo ocidental, a qual contou com o poderoso apoio do pensamento e do ideário das Luzes, bem como de suas aporias. Desse modo, se o Ocidente não teve no seu passado uma Biblioteca de Alexandria, perdida para sempre, mas viva em seus sonhos e no seu imaginário ${ }^{32}$, o que nos lembra da tradição erudita do Oriente - por isso mesmo há quem situe geograficamente a desaparecida biblioteca nas bordas do Mediterrâneo -, autofigurado na imagem de uma centralidade incontornável, o Ocidente encontrou respaldo no poder de uma utopia de civilização voltada para a construção de um imenso espaço público, de tipo globocêntrico, conectado pelos livros.

Não por acaso o escritor Orhan Pamuk, em $A$ maleta de meu pai (2007), nos fala do sentimento de estar fora do centro, de habitar nas margens, o que foi um peso sobre ele quando decidiu escrever, bem como sobre o pai que sonhava em ser escritor. Ambos, ele nos diz, queriam ser escritores não da literatura mundial, mas ocidental, da qual eles, os turcos, sentiam-se excluídos. E diz:

A biblioteca de meu pai era prova disso. Numa ponta, ficavam os livros de Istambul, a nossa literatura, o nosso mundo local, [...] e, na outra, ficavam os livros daquele outro mundo, o mundo ocidental, com o qual a Turquia náo se parecia em nada. Uma dessemelhança que nos causava dor e, ao mesmo tempo, nos trazia esperanças. Escrever ou ler era como deixar o nosso mundo para procurar consolo na alteridade, em seu caráter estrangeiro e fabuloso (PAMUK, 2007, p. 22).

Afinal, a utopia construída pelo Ocidente pretendeu, de forma genesíaca, tomar para si a elaboração de uma grande memória da cultura escrita e da cultura impressa. Nesse ponto cabe alertar o leitor de que o Ocidente, tal como a modernidade, não são blocos monolíticos e tampouco a experiência da modernidade pode ser vista como algo homogêneo e naturalizado. É preciso ter em conta suas nuances ao falar de um e de outro, no que toca às condiçôes de sua emergência, seus referenciais letrados, seu pertencimento cultural, suas permeabilidades. Isto não elimina, no entanto, um aspecto fundamental: no Ocidente e na mo-

\footnotetext{
${ }^{31}$ Tradução da autora. No original: "El mundo existe para llegar a un libro".

${ }^{32}$ Sobre isso, ver as análises sensíveis de Canfora (1986); Jacob (1996); Goulemot (2006); e Manguel (2006).
} 
dernidade há caminhos que se bifurcam. Seja no caso de um projeto de civilização europeu posto em marcha já no alvorecer do mundo moderno, posteriormente aprofundado, e que se espraia pelos outros continentes com códigos, práticas e convençóes cuja historicidade, entretanto, não elimina os muitos pontos de contato e a "efetividade" desse mesmo projeto, seja no caso da ampla circulação de textos e livros, e do cipoal de estratégias de apropriação dos livros e de práticas de leitura e letramento que daí decorrem. Portanto a presença de um ideal civilizatório se realizou através de várias e diferentes cadeias de transmissóes pelas quais transitaram os avanços e as inovaçóes da edição, da indústria editorial e do comércio dos livros, e circularam simbolismos em torno do livro e da leitura, ainda que assumindo formas diversas, inconstantes e, por vezes, transgressivas ${ }^{33}$.

O culto dos livros e das promessas a ele associadas na sociedade e nas comunidades de leitores, bibliófilos e colecionadores carregam muitas vezes em uma versão negativa, de perda, as representaçôes e também as ilusôes construídas em torno do poder e do mito dos livros e das leituras quando em frente às revolucionárias transformaçóes tecnológicas concretizadas nos novos suportes de leitura e meios de produção e difusão de textos. Na contemporaneidade, as tensôes e contradiçôes associadas àquelas forças imaginárias seguem firmes em meio aos avanços teóricos e aos debates em torno das teorias da recepção, da função-autor, do papel do leitor, das performances dos textos, das crises e/ou impossibilidades da leitura e da literatura, e da possível morte do autor e do leitor frente às fraturas da pós-modernidade. A utopia que teve o livro como um dos centros da identidade do Ocidente - que segue persistente em inúmeras tópicas - se tem como seu reverso a problematização do significado histórico e possíveis efeitos da nova revolução do livro ${ }^{34}$, no limite, acaba por nutrir um temor frente às novas tecnologias, vistas como uma ameaça à desaparição de uma cultura do livro e da leitura, diferentemente do que foi profetizado com alegria visionária por Octave Uzanne no seu $O$ fim dos livros, que não foi um fim!

\footnotetext{
${ }^{33}$ Essa possibilidade é bem explorada na ficção com Mr. Todd, personagem do livro de Evelyn Waugh, Um punhado de pó (1987). Mestiço, filho de um missionário inglês com uma mulher indígena, privado do aprendizado da leitura, Mr. Todd transforma em prisioneiro um aristocrata inglês que ele resgata de um naufrágio nas costas da Guiana Inglesa, condenando-o a passar os restos dos seus dias a ler e reler em voz alta os livros de Charles Dickens que pertenceram ao seu pai, e que ele não podia ler. Nesse livro o leitor se encontra diante de uma inversão do poder que se exerce do conquistado sobre o conquistador, do iletrado sobre o letrado, do mestiço sobre a nobreza aristocrática, em torno do objeto simbólico mais precioso da cultura dos impérios coloniais: o livro, produto de cultura, instrumento-chave da troca cultural e do trânsito entre as culturas da Europa e das Américas. O livro nessa ficção é instrumento que evoca a vingança em relação à figura do pai, a qual é revestida de um duplo sentido: contra o colonizador inglês e sua condição de homem cultivado.

${ }^{34}$ A exemplo dos já citados autores Jean-Yves Mollier, Roger Chartier, Alberto Manguel, Antoine Compagnon, Umberto Eco e Jean-Claude Carrière.
} 


\section{Referências}

BENJAMIN, Walter. Desempacotando minha biblioteca. Um discurso sobre o colecionador. In: BENJAMIN, Walter. Rua de mão única. Obras Escolhidas, v. II. São Paulo: Brasiliense, 1987. p. 227-235.

BIRCHAL, Telma de Souza. O eu nos ensaios de Montaigne. Belo Horizonte: Editora UFMG, 2007.

BONNET, Jacques. Des bibliothèques pleines de fantômes. Paris: Denoël, 2008.

BORGES, Jorge Luis. Obras completas, v. I e II. Buenos Aires: Emecé Editores, 1974.

CALVINO, Ítalo. As cidades invisiveis. São Paulo: Companhia das Letras, 1990.

CALVINO, Ítalo. Se um viajante numa noite de inverno. São Paulo: Companhia das Letras, 1999.

CANFORA, Luciano. A biblioteca desaparecida. Histórias da Biblioteca de Alexandria. São Paulo: Companhia das Letras, 1986.

CANETTI, Elias. Auto de fé. Rio de Janeiro: Nova Fronteira, 1991.

CARROLL, Lewis. Aventuras de Alice no País das Maravilhas. Através do espelho e o que Alice encontrou por lá. São Paulo: Zahar, 2009.

CHARTIER, Roger. Literature and written culture: stability of words, mobility of texts, plurality of readings. In: CHARTIER, Roger. The cultural revolution of the nineteenth century: theatre, the book-trade and reading in the transatlantic world. Edited by Marcia Abreu and Ana Cláudia Suriani da Silva. London/New York: I. B. Tauri Co. Ltd, 2016.

CHARTIER, Roger. A mão do autor e a mente do editor. São Paulo: Editora UNESP, 2014. CHARTIER, Roger. Mort ou transfiguration du lecteur? In: MOLLIER, Jean-Yves (dir.) Où va le livre? Paris: La Dispute, 2002. p. 295-311.

COMPAGNON, Antoine. O demônio da teoria. Literatura e senso comum. Belo Horizonte: Editora UFMG, 2001.

COMPAGNON, Antoine. Un monde sans auteur? In: MOLLIER, Jean-Yves, (dir.) Où va le livre? Paris: La Dispute, 2002. p. 275-294.

DE BES, Fernando Trias. Tinta. Belo Horizonte: Autêntica, 2013.

DOMÍNGUEZ, Carlos Maria. A casa de papel. São Paulo: Francis, 2006.

DOSTOIÉVSKI, Fiódor. Crime e Castigo. São Paulo: Editora 34, 2009.

ECO, Umberto; CARRIÈRE, Jean-Claude. Não contem com o fim do livro. Rio de Janeiro: Record, 2010.

FITZGERALD, Penélope. A livraria. Rio de Janeiro: Bertrand, 2000.

FREUD, Sigmund [1919]. O estranho. In: Edição Standard Brasileira das Obras Psicológicas 
Completas, v. XVII. Rio de Janeiro: Imago, 1976.

GINZBURG, Carlo. Sinais, raízes de um paradigma indiciário. In: GINZBURG, Carlo. Mitos, emblemas e sinais. São Paulo: Companhia das Letras, 1989.

GOULEMOT, Jean-Marie. L'amour des bibliothèques. Paris: Seuil, 2006.

HOFFMANN, E. T. A. A senhorita de Scuderi. Rio de Janeiro: Civilização Brasileira, 2012. JABLONKA, Ivan. La Historia es una literatura contemporánea. Manifiesto por las ciencias sociales. 1. ed. Ciudad Autónoma de Buenos Aires: Fondo de Cultura Económica, 2016.

JACOB, Christian. Lire pour écrire: navigations alexandrines. In: BARATIN, Marc; JACOB, Christian. Le pouvoir des bibliothèques. La mémoire des livres en Occident. Paris: Albin Michel, 1996.

LUCCHESI, Marco. O bibliotecário do Imperador. Rio de Janeiro: Ed. Biblioteca Azul, 2013.

MANGUEL, Alberto. Biblioteca à noite. São Paulo: Companhia das Letras, 2006.

MCKENZIE, Donald F. La bibliographie et la sociologie des textes. Paris: Éditions du Cercle de la Librairie, 1991.

MOLLIER, Jean-Yves (dir.) Où va le livre? Paris: La Dispute, 2002.

MONTAIGNE, Michel de. Do desmentir. In: MONTAIGNE, Michel de. Ensaios, Livro II, São Paulo: Martins Fontes, 2000-2001a.

MONTAIGNE, Michel de. Do arrependimento. In: MONTAIGNE, Michel de. Ensaios, Livro III. São Paulo: Martins Fontes, 2000-2001b.

MORAES SILVA, Antonio de. Dicionário da língua portuguesa. Lisboa: Lacerdina, 1813.

MORAES SILVA, Antonio de. Grande dicionário da língua portuguesa. Lisboa: Editorial Confluência, 1948.

OUVRY-VIAL, Brigitte. L'acte éditorial: vers une théorie du geste. Communication et Langage, Paris, n. 154, p. 67-82, 2007.

PAMUK, Orhan. A maleta de meu pai. São Paulo: Companhia das Letras, 2007.

PIGLIA, Ricardo. O último leitor. São Paulo: Companhia das Letras, 2006.

POE, Edgar Allan. Histoires extraordinaires. Traduction de Charles Baudelaire. Paris: Bookking International, 1966.

RICOEUR, Paul. Tempo e narrativa. Tomo I-II. Campinas, SP: Papirus, 1994.

RICOEUR, Paul. La mémoire, l'histoire, l'oubli. Paris: Seuil, 2000.

SEBALD, W. G. Os anéis de saturno. São Paulo: Companhia das Letras, 2010.

TAYLOR, Diana. O arquivo e o repertório. Performance e memória cultural nas Américas. Belo Horizonte: Editora UFMG, 2013.

TOSCANA, David. O último leitor. Rio de Janeiro: Casa da Palavra, 2005. 
UZANNE, Octave. O fim dos livros. São Paulo: Octavo, 2010.

VALÉRY, Paul. Eupalinos ou l'architecte. Paris: NRF/Gallimard, 2008.

WALSH, Rodolfo. Variaçôes em vermelho e outros casos de Daniel Hernández. São Paulo: Editora 34, 2011.

WAUGH, Evelyn. Um punhado de pó. São Paulo: Companhia das Letras, 1987.

ZIVKOVIC, Zoran O último livro. São Paulo: Octavo, 2012. 